\title{
CORRECTION
}

View Article Online

View Journal | View Issue

Check for updates

Cite this: J. Mater. Chem. A, 2017, 5, 22389

DOI: $10.1039 / c 7 t a 90221 b$

www.rsc.org/MaterialsA

\section{Correction: Metal-functionalized covalent organic frameworks as precursors of supercapacitive porous $\mathbf{N}$-doped graphene}

Jorge Romero, ${ }^{a}$ David Rodriguez-San-Miguel, ${ }^{\text {bc }}$ Antonio Ribera, ${ }^{a}$ Rubén MasBallesté, ${ }^{b}$ Toribio F. Otero, ${ }^{d}$ Ilse Manet, ${ }^{e}$ Fabiola Liscio, ${ }^{f}$ Gonzalo Abellán, ${ }^{\star a g}$

Felix Zamora*bc and Eugenio Coronado*a

Correction for 'Metal-functionalized covalent organic frameworks as precursors of supercapacitive porous N-doped graphene' by Jorge Romero et al., J. Mater. Chem. A, 2017, 5, 4343-4351.

The authors regret the misspelling of one author name, Fabiola Liscio. The corrected author list for this paper is shown above.

The Royal Society of Chemistry apologises for these errors and any consequent inconvenience to authors and readers. 